\title{
Effects of different dose regimens of Milrinone on hemodynamics and Left ventricular systolic function after cardiopulmonary bypass.
}

\author{
Mohamed Abdel Rahman Salem M.D*, Moh. A. Mourad M.D**, Salah \\ Kasem M.D***, Ahmad Abdul Monem Emam M.D\# . \\ *Anesthesia department faculty of medicine Menofeyia university, ** Anesthesia \\ department National heart institute, ${ }^{* * *}$ Anesthesia department faculty of medicine Ain \\ Shams university, Cardiology department National Heart Institute\#.
}

\begin{abstract}
Milrinone can improve myocardial systolic function and hemodynamics by increasing contractility and decreasing afterload, although its appropriate dose regimen has not yet been established for cardiac surgical patients. Despite milrinone effectively increases cardiac function after cardiopulmonary bypass, few studies have specifically evaluated its efficacy during cardiac surgery. We investigated the effects of milrinone on hemodynamics and left systolic ventricular function in cardiac surgical patients immediately after emergence from cardiopulmonary bypass (CPB). Forty five patients undergoing cardiac surgery were studied. They received milrinone $(25,50$, or $75 \mathrm{ug} / \mathrm{kg})$ bolus dose over ten minutes followed by $0.25,0.5,0.75 \mathrm{ug} / \mathrm{kg} / \mathrm{min}$ in three patients groups. Heart rate, mean arterial blood pressure, pulmonary capillary wedge pressure, and cardiac index were determined before and after the administration of milrinone and transesophageal echocardiogram were recorded while constant filling pressures were maintained by volume reinfusion from the CPB reservoir. All three doses of milrinone significantly increased CI ( 2.5, 3.1,3.2 L/min/m²), HR (98, 96,100 bpm), SV ( 61,66,67 $\mathrm{ml} /$ beat $)$ and $\mathrm{EF}(61,66,66 \%)$ after $5 \mathrm{~min}$ from the milrinone use $(\mathrm{p}<0.001)$ and significantly decreased the MAP $(80,81,82 \mathrm{mmHg}), \operatorname{SVR}\left(1127,965,928\right.$ dyn.s.cm ${ }^{-5}$ ) and PVR $\left(183,165,157\right.$ dyn.s.cm $\left.{ }^{-5}\right)$ at the same time interval $(\mathrm{p}<0.001)$ while the PCWP and CVP did not show valuable change. The 50- and $75-\mathrm{ug} / \mathrm{kg}$ doses produced significantly larger increases in cardiac index than the $25-\mathrm{ug} / \mathrm{kg}$ dose; however, the 75 $\mathrm{ug} / \mathrm{kg}$ dose did not produce a significantly larger increase in cardiac index than did the $50-\mathrm{ug} / \mathrm{kg}$ dose. Two patients receiving milrinone $25 \mathrm{ug} / \mathrm{kg}$ developed premature ventricular contractions. The $75-\mathrm{ug} / \mathrm{kg}$ dose was associated with a case of ventricular tachycardia treated with xylocaine infusion and three cases of severe hypotension (BP $<60 \mathrm{mmHg}$ ) requiring phenylephrine infusion and IV fluid replacement. Thus, milrinone improves hemodynamics and left ventricular systolic function when constant loading conditions are maintained.
\end{abstract}




\section{Introduction}

Patients undergoing cardiac
surgery often exhibit myocardial
dysfunction after cardiopulmonary
bypass (CPB) ${ }^{1-2}$. The etiology is
multifactorial, with possible causes
including incomplete myocardial prote ction, effects of cardioplegia solutions, global ischemia, and reperfusion injury. The severity and duration of cardiac depression after cardiopulmonary bypass (CPB) corre -lates with the duration of ischemia ${ }^{3}$. Both betaadrenergic agonists and phospho diesterase III inhibitors (PDEIII) are frequently used to improve myocardial performance after cardiopulmonary bypass. These two classes of agents exert both their inotropic and vasod ilatory effects by different mechanisms. Clinical and experimental data have demonstrated that the heart exhibits acute $B$-adrenergic receptor desensitiz ation during $\mathrm{CPB}$; this results in decreased cyclic adenosine monoph osphate (cAMP) production after stimulation of the $B$ adrenergic receptors 4-5. Thus, large doses of $\beta$ - agonists may be required to improve contractility, leading to increased myocardial oxygen consumption and the risk of myocardial ischemia and arrhythmias 6 . PDEIII inhibition results in the decrease in left ventricular (LV) wall stress, LV preload reduction, positive inotropic effect, direct coronary vasod -ilatation, and improvement of myocardial function without an increase in myocardial oxygen consumption. This may be of beneficial specifically in patients with limited coronary flow reserve ${ }^{7-8}$. Milrinone is a nonglyc osidic, nonsympathomimetic drug that increases myocardial cyclic adenosine monophosphate concentration by selective inhibition of cardiac phosphodiesterase fraction III (cAMPspecific). It also increases calcium delivery to the contractile system, thereby increasing myocardial contra ctility. Milrinone has nearly 20 times the inotropic potency of amrinone ${ }^{9-10}$.

\section{Aim of work}

The purpose of this study was to investigate whether the adminis tration of milrinone immediately after aortic cross-clamping improved hemo -dynamics and LV systolic function after CPB in cardiac patients ( ischemic or valvular) subjected to open heart procedures and whether any difference would be observed between different milrinone dose regimens.

\section{Patients and Methods}

Anesthetic Management

After approval from the local ethical committee and informed written consent, 45 adult patients with either ischemic heart or valvular heart diseases electively scheduled for coronary artery bypass or valve replacement operations requiring $\mathrm{CPB}$ were studied. Exclusion criteria included emergency surgery, history of recurrent ventricular tachyca rdia, obstructive cardiomyopathy, combined CABG-valvular surgery, patients in cardiogenic shock; or history of esophageal disease, precluding the insertion of the transesophageal echocardiographic (TEE) probe. Preoperative routine physical examinations and investigations were done including preoperative ECG, echocardiography, cardiac catheteriza tion and routine laboratory work, CBC, serum electrolytes, liver and kidney function tests. Preoperative medication consisted of intramuscular morphine 0.1 $\mathrm{mg} / \mathrm{kg}$ and midazolam $0.15 \mathrm{mg} / \mathrm{kg}$. 
Anesthesia was induced with fentanyl (10 $\mathrm{mg} / \mathrm{kg})$, midazolam (0.05-0.1 $\mathrm{mg} / \mathrm{kg})$, and pancuronium (0.1-0.2 $\mathrm{mg} / \mathrm{kg}$ ), and the patients were ventilated with $100 \%$ oxygen. Monitors for patients were included five leads electrocardiography, radial and pulmo nary arterial catheters (HP Component Monitoring System M1094A; Hewlett Packard, Palo Alto, CA), and TEE. Systolic pressure, diastolic pressure, mean arterial pressure (MAP), pulmo nary artery pressure, and heart rate (HR) were measured continuously. Cardiac output (CO) was determined by the thermodilution technique with $10 \mathrm{~mL}$ cold saline using Criticath ${ }^{\mathrm{TM}}$ SP $5107 \mathrm{H}$ TD pulmonary artery catheter (Becton Dickinson critical system). Baseline hemodynamic data and a LV short-axis view were recorded after induction of anesthesia. In all patients, CPB was conducted using a membrane oxygen ator and mild systemic hypothermia (minimum temperature $34^{\circ} \mathrm{C}$ ). $\mathrm{CPB}$ was conducted using a nonpulsatile flow of 2.5-3.5 $\mathrm{L} / \mathrm{min} / \mathrm{m}^{2}$. The circuit was primed with $1500 \mathrm{ml}$ balanced salt solution, $250 \mathrm{ml} \quad 10 \%$ mannitol. Multidose cold crystalloid cardioplegia was used for myocardial protection during CPB. For $\mathrm{pH}$ management, $\alpha$ stat methodology was used, and activated clotting times was maintained $>400$ s. Distal anastomoses were usually performed first during continuous aortic cross-clamping, followed by proximal vein grafting during partial aortic occlusion. After the primary surgical procedure, patients were warmed to a temperature of $36.5-37^{\circ} \mathrm{C}$. The heart was defibrillated after cardiac reperf usion if sinus rhythm did not resume spontaneously, epicardial pacing at a rate of $80 \mathrm{bpm}$ was used as needed for sinus bradycardia or atrioventricular conduction disturbances.

\section{Hemodynamic Measurements}

The following hemodynamic variables were recorded after induction of anesthesia as a baseline readings: heart rate (HR), mean arterial blood pressure (MAP), mean pulmonary artery blood pressure (MPAP), central venous pressure (CVP), pulmonary capillary wedge pressure (PCWP), and cardiac index (CI). CI was calculated at each $\mathrm{CO}$ measurement automatically. All measurements were taken during the expiratory pause phase of the ventilator cycle. Systemic and pulmonary vascular resistance (SVR and PVR), and stroke volume (SV) were calculated from measured variables using standard equations. Patients were weaned from CPB, if SBP did not reach $>90 \mathrm{~mm} \mathrm{Hg}$ a continuous infusion of phenylephrine $(10-100$ $\mathrm{ug} / \mathrm{min}$ ) was started prior to removal of the aortic cross clamp. Patients were randomly assigned to one of treatment groups: group (A) $25 \mu \mathrm{g} / \mathrm{kg}$ bolus +0.25 $\mu \mathrm{g} / \mathrm{kg} /$ min continuous infusion $(\mathrm{n}=15)$, group (B) $50 \mu \mathrm{g} / \mathrm{kg}$ bolus + $0.5 \mu \mathrm{g} / \mathrm{kg} / \mathrm{min}$ continuous infusion $(\mathrm{n}=$ 15), or group (C) $75 \mu \mathrm{g} / \mathrm{kg}$ bolus + $0.75 \mu \mathrm{g} / \mathrm{kg} / \mathrm{min}$ continuous infusion $(\mathrm{n}=$ 15). Continuous infusions were initiated after a loading dose administered over 10 min. After baseline, the hemodynamic measurements were repeated at 5, 10, and 20 min. Transesophageal echocardiography (TEE) was continuously assessing LV systolic function during milrinone administration and recordings were made simultaneously when hemod ynamic measurements were obtained.

Transesophageal Echocardiography

The TEE probe (adult multi-plane MPZ 7-4 ALT 5000 transesophageal ultrasound probe connected to an 
echocardiography unit - ALT-HDI 5000 model AGMD 835 E) was positioned behind the left ventricle and a short axis view of the left ventricle at the midpapillary muscle level was continuously monitored after induction of general anesthesia. Multiple tomographic cuts with twodimensional echocardiography was obtained and utilized to calculate left ventricular end systolic volume (ESV), end diastolic volume (EDV) and ejection fraction (EF). The LV endocardium at the apical 4-chamber and apical 2-chamber at the end of diastole was traced to obtain the ED volume, while maintaining a constant left atrial pressure. It was also traced at the end of systole to obtain volume and hence the average EF\% could be calculated by the echo-machine. The LV end-diastole was identified by the peak of the R-wave and the endsystole was identified by the minimum $\mathrm{LV}$ dimensions at the end of T-wave. A number of techniques are available for estimation of the LV volumes and EF by 2-D echocardiography, the Simpson's method is the one used in this study. It divides the LV cavity into multiple slices (20 sections) of known thickness and diameter D (by taking several short-axis views at different levels along the LV long axis) and then calculating the volume of each slice (area $\mathrm{x}$ thickness). The area is $\pi$ (D $\mathrm{x} \mathrm{2)^{2 }}$. The thinner the slices, the more is accurate the estimation of LV volume.

Statistical Analysis of the present stud Statistical analysis was perfor med on hemodynamic data and echoca rdiographic variables by one-way and two-way analysis of variance (ANOVA) to compare changes within each group and paired Student s test to compare two different groups data. Statistical analysis was conducted using statistical software (SPSS). $\mathrm{P}<0.05$ was considered statistically significant, and all data are expressed as mean \pm SD.

\section{Results}

Demographic and preoperative data for the milrinone groups are described in patients undergoing coronary artery bypass grafts, aortic valve replacement, and mitral valve replacement as seen in table (1) were studied. There were no significant differences in age, gender, weight, height, body surface area, aortic crossclamp time, or CPB time. Likewise, patients had similar incidences of diabetes mellitus and hypertension, were receiving similar preoperative medications, had the same baseline routine laboratory work and underwent similar operative procedures.

Table (1) Preoperative and demographic data:

\begin{tabular}{|c|c|c|c|}
\hline Parameter & Group A & Group B & Group C \\
\hline Age $(\mathrm{y})$ & $49 \pm 5$ & $48 \pm 6$ & $50 \pm 7$ \\
Gender M/F & $8 / 7$ & $10 / 5$ & $11 / 4$ \\
Weight $(\mathrm{kg})$ & $78 \pm 8$ & $75 \pm 10$ & $80 \pm 7$ \\
Height $(\mathrm{cm})$ & $176 \pm 12$ & $174 \pm 15$ & $178 \pm 14$ \\
BSA (m $\left.{ }^{2}\right)$ & $1.89 \pm 0.11$ & $1.90 \pm 0.13$ & $1.87 \pm 0.09$ \\
Cross clamp time & $56 \pm 13$ & $62 \pm 11$ & $58 \pm 15$ \\
CPB time (min) & $118 \pm 31$ & $132 \pm 22$ & $126 \pm 25$ \\
Operation CABG & 7 & 4 & 5 \\
AVR & 3 & 4 & 4 \\
MVR & 5 & 7 & 6 \\
\hline
\end{tabular}

$\mathrm{BSA}=$ body surface area, $\mathrm{CABG}=$ coronary artery bypass grafting, $\mathrm{MVR}=$ mitral valve replacement, $\mathrm{AVR}=$ aortic valve replacement. 
Table (2) Hemodynamic data in different Milrinone groups:

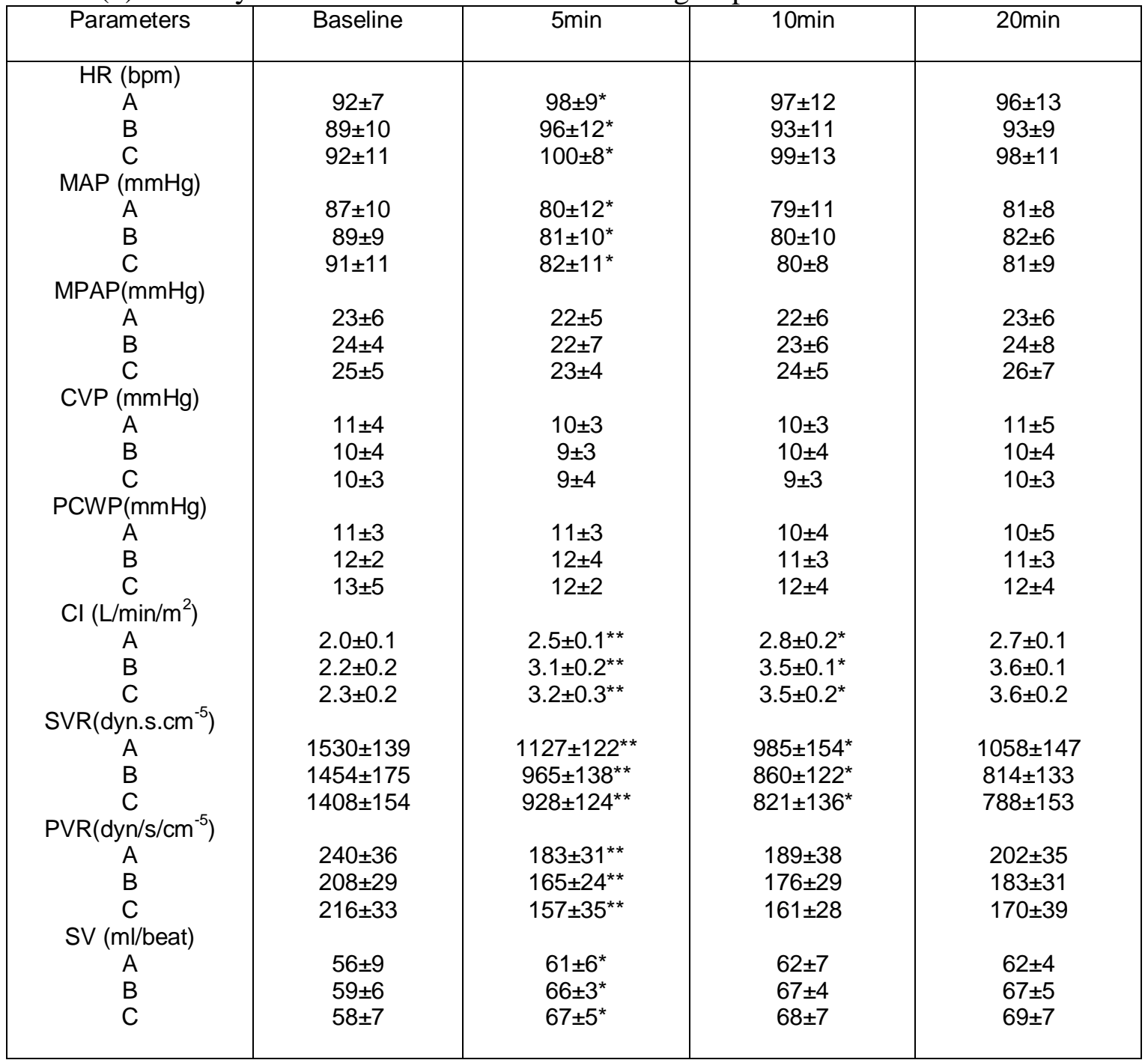

$\mathrm{HR}=$ heart rate, $\mathrm{MAP}=$ mean arterial pressure, MPAP=mean pulmonary artery pressure, $\mathrm{CVP}=$ central venous pressure, $\mathrm{PCWP}=$ pulmonary capillary wedge pressure, $\mathrm{CI}=$ cardiac index, SVR=systemic vascular resistance, $\mathrm{PVR}=$ pulmonary vascular resistance, $\mathrm{SV}=$ stroke volume, $* * \mathrm{P}<0.001, * \mathrm{P}<0.05$.

The changes in hemodynamic variables in each group after emergence from CPB are summarized in table (2). A baseline recordings, showed no significant difference in hemodynamic variables among all groups.

In all milrinone groups, HR significantly increased from baseline at $5 \mathrm{~min}(10 \%)$ but other time intervals at 10 and 20 min did not show significant change $(\mathrm{p}<0.05)$. Two patients in group A developed ventricular premature contractions after the start of the milrinone infusion and one patient in group C developed a run of ventricular tachycardia which was treated by xylocaine $1 \mathrm{mg} / \mathrm{kg}$ bolus dose followed by $50 \mathrm{ug} / \mathrm{kg} / \mathrm{min}$ continuous infusion.

Mean arterial pressure (MAP) was significantly decreased after 5 min $(8-12 \%)$ and $p<0.001$ without significant change in the other time intervals. Three patients in group $\mathrm{C}$ developed severe hypotension after the 
bolus dose $(<60 \mathrm{mmHg})$ that required phenylephrine infusion, blood from the pump-oxygenator, and IV fluid. The median total volumes (in milliliters) of blood and IV fluid transfused during the first $10 \mathrm{~min}$ after the milrinone loading doses were: $450 \mathrm{ml}$ (range, 410-500 $\mathrm{ml}$ ), $630 \mathrm{ml}$ (range 450-800 $\mathrm{ml}$ ), and $860 \mathrm{ml}$ (range 380-1040 $\mathrm{ml}$ ), respectively, for the 25,50 , and 75 $\mathrm{ug} / \mathrm{kg}$ doses $(\mathrm{P}=\mathrm{NS})$. There were no other significant changes in mean arterial pressure relative to baseline at any time in any of the three groups.

Likewise, there were no significant differences between the three dose groups at any time. No significant changes in MPAP, PCWP, or CVP were observed in milrinone groups.

Table (3) Echocardiographic data in different milrinone groups

\begin{tabular}{|c|c|c|c|c|}
\hline parameters & Baseline & $5 \mathrm{~min}$ & $10 \mathrm{~min}$ & $20 \mathrm{~min}$ \\
\hline EDV $(\mathrm{ml})$ & & & & \\
A & $108 \pm 5$ & $99 \pm 4^{\star *}$ & $97 \pm 5$ & $97 \pm 4$ \\
B & $112 \pm 6$ & $100 \pm 5^{\star \star}$ & $96 \pm 4$ & $95 \pm 4$ \\
C & $110 \pm 5$ & $101 \pm 4^{\star *}$ & $96 \pm 6$ & $98 \pm 3$ \\
ESV $(\mathrm{ml})$ & & & & \\
A & $51 \pm 4$ & $38 \pm 5^{\star \star}$ & $35 \pm 4$ & $35 \pm 5$ \\
B & $52 \pm 4$ & $34 \pm 4^{\star *}$ & $30 \pm 5$ & $29 \pm 3$ \\
C & $52 \pm 3$ & $34 \pm 3^{\star *}$ & $28 \pm 6$ & $26 \pm 4$ \\
EF\% & & & & \\
A & $52 \pm 4$ & $61 \pm 3^{\star *}$ & $63 \pm 4$ & $63 \pm 3$ \\
B & $54 \pm 3$ & $66 \pm 4^{\star *}$ & $70 \pm 5^{\star}$ & $71 \pm 3$ \\
C & $53 \pm 4$ & $66 \pm 3^{\star *}$ & $71 \pm 4^{*}$ & $72 \pm 5$ \\
\hline
\end{tabular}

$\mathrm{EDV}=$ end-diastolic volume, $\mathrm{ESV}=$ end-systolic volume, $\mathrm{EF}=$ ejection fraction, $* * \mathrm{p}<0.001, * \mathrm{p}<0.05$.

Milrinone significantly increased cardiac index at all three groups. It is significantly increased $(20 \%$ in group A and $32 \%$ in group B and C) from the baseline. In comparison, between the milrinone groups, CI was significantly higher at $5 \quad(\mathrm{P}<0.001)$ and $10 \mathrm{~min}$ $(\mathrm{p}<0.05)$ in all milrinone groups then maintained at $20 \mathrm{~min}$. There were no significant differences between the 50and $75-\mathrm{ug} / \mathrm{kg}$ doses at any time point. In the $25-\mathrm{ug} / \mathrm{kg}$ dose group, cardiac index significantly increased relative to baseline by the 5-min measurement and remained significantly increased until the 20-min measurement. In the 50 and $75-\mathrm{ug} / \mathrm{kg}$ dose group, cardiac index was significantly increased relative to baseline at all measurements.
Pulmonary vascular resistance and systemic vascular resistance significantly decreased (14\% and 23\% respectively) from the baseline at $5 \mathrm{~min}$ $(p<0.001)$ and $10 \mathrm{~min}(\mathrm{p}<0.05)$ for SVR only. SV was significantly increased after 5 min $(p<0.05)$. Echocardiographic variables are presented in table (3). There were no significant differences in EDV, ESV or EF baseline readings between the milrinone groups. EF significantly increased from the baseline at $5 \mathrm{~min}$ in all groups $(\mathrm{p}<0.001)$ and $10 \mathrm{~min}$ in group $\mathrm{B}$ and $\mathrm{C}(\mathrm{P}<0.05)$. EDV and ESV were significantly decreased at $5 \mathrm{~min}$ $(\mathrm{P}<0.001)$ in all milrinone groups. 


\section{Discussion}

Weaning from $\mathrm{CPB}$ after cardiac surgery is a major problem in the patient with congestive heart failure or ventricular dysfunction. $\beta_{1}$-adrenergic receptor down-regulation may contribute to difficulty in weaning from CPB with catecholamines and vasodilators. Since the PDE III inhibitor can bypass $\beta_{1}$-adrenergic receptors to increase cAMP and improve myocardial contractility ${ }^{11,12,13}$. After emergence from $\mathrm{CPB}$ in cardiac surgical patients presented in this study, milrinone loading doses $(25,50,75 \mathrm{ug} / \mathrm{kg})$ plus continuous infusion $(0.25, \quad 0.5,0.75$ $\mathrm{mg} / \mathrm{kg} / \mathrm{min}$ ) were shown to effectively improve hemodynamics and LV systolic function. These regimens were associated with significant increase in $\mathrm{HR}$ and a significant decrease in MAP when preload as assessed by PCWP and EDV was maintained constant. This study also confirmed that milrinone increases cardiac index in a dosedependent manner and decreases both PVR and SVR in cardiac surgical patients. The 50- and 75-ug/ $\mathrm{kg}$ doses were more efficient than the $25-\mathrm{ug} / \mathrm{kg}$ dose. The $75-\mathrm{ug} / \mathrm{kg}$ dose produced no greater increase in cardiac index than the $50-\mathrm{ug} / \mathrm{kg}$ dose, on the other hand, it was associated with a single case of ventricular tachycardia. Thus, it is recommend that $50 \mathrm{ug} / \mathrm{kg}$ be used as the initial milrinone bolus dose in cardiac surgical patients after cardiopulmonary bypass. The IV use of milrinone has been reported to increase CI and decrease LV preload and afterload in patients with chronic heart failure ${ }^{17}$. Previous studies conducted after cardiac surgery demonstrated that a loading dose plus continuous infusion of milrinone successfully increased $\mathrm{CO}$ with a decrease in PCWP and systemic vascular resistance, which indicates that milrinone is effective in emergence from CPB ${ }^{14,15,16}$. In another study, Butterworth et al. also demonstrated that a $50-\mathrm{ug} / \mathrm{kg}$ bolus dose of milrinone increased $\mathrm{CI}$ after $\mathrm{CPB}{ }^{18}$.

Although thermodilution $\mathrm{CO}$ facilitates the clinical assessment of cardiac function, it is dependent on LV preload, afterload, and myocardial contractility, all of which may be altered under milrinone administration. Taking this into account, TEE analysis of LV function was performed. Changes in EDV by two-dimensional echocardiography reflect the change in LV preload. This study demonstrated that EDV was significantly reduced with milrinone use ${ }^{15}$.

In previous reports, milrinone has been shown to reduce ventricular afterload. These trends toward decrease in LV afterload were observed in the present in all groups as documented by the significant decrease in systemic vascular resistance ${ }^{16}$. The ejection fraction was significantly increased with milrinone in 5 and 10 minutes in all groups which suggested a positive inotropic effect of milrinone.

There are limitations to the present study. The patients undergoing different kinds of operations, and differences of the disease pathology at the cellular level and the responses to milrinone must be considered in interpreting the results of this study. However, no significant difference was observed in the demographic data among the study groups, and the bias due to the variety of the operations is thought to have minimum influence on the results. Also, in the search for an optimal dosage regimen of milrinone in cardiac surgical patients, the need for vasoconstrictors should be evaluated.

In conclusion, milrinone administered as a loading dose plus a continuous infusion effectively 
increased CI, EF and HR and decreased MAP, PVR and SVR immediately after emergence from CPB. A $50-\mathrm{ug} / \mathrm{kg}$ dose of milrinone is effective and achieves adequate hemodynamics with minimal side effects as compared with $25-$ and $75-\mathrm{ug} / \mathrm{kg}$ doses. Only one patient demonstrated severe arrhythmia after receiving milrinone in a dose of 75 $\mathrm{ug} / \mathrm{kg}$.

\section{References}

1. Higgins $T$, Yared J,RyanT. Immediate postoperative care of cardiac surgical patients. J Cardiothorac Vasc Anesth 1996; 10: 643-58.

2. Teoh K, Christakis G, Weisel R, et al. Increased risk of urgent revascularization. J Thorac Cardiovasc Surg 1987; 93: 291-9.

3. Briesblatt W, Wolfe C, Follansbee $\mathrm{W}$, et al. Acute myocardial dysfunction and recovery: a common occurrence after coronary artery bypass. J Am Coll Cardiol 1990; 15: 1261-7.

4. Booth JV, Landolfo KP, Chesnut LC, et al. Acute depression of myocardial $B$-adrenergic receptor signaling during cardiopulmonary bypass. Anesthesiology 1998; 89: 602-11.

5. Doman BH, Cavallo MJ, Spinale FG, The direct and interactive effects of phosph-diesterase inhibition and $B$-adrenergic stimulation on myocyte contractile function after hypothermic cardioplegic arrest. Anesth Analg 1995; 81: 925-31.

6. Bristow MR, Ginsburg R, Minobe $\mathrm{W}$, et al. Decreased catecholamine sensitivity and beta-adrenergic receptor density in failing human hearts. N Engl J Med 1982; 307: 205-11.
7. Baim DS. Effect of phospho diesterase inhibition on myocardial oxygen consumption and coronary blood flow. Am J Cardiol 1989; 63: 23A-26A.

8. DiBianco R. Acute positive inotropic intervention: the phosphodiesterase inhibitors Butcher RW, Sutherland EW Am Heart J 1991; 121 (6 Pt 1):1871-5.

9. Rump AFE, Acar D, Klaus W. A quantitative comparison of functional and anti-ischaemic effects of the phosphodiesteraseinhibitors, amrinone, milrinone and levosimendan in rabbit isolated hearts. Br J Pharmacol 1994; 112: 757-62.

10. Sidi A, Pool JM, Rush W. Early administration of amrinone does not impair regional metabolism of $\mathrm{O}_{2}$ or lactate and, by improving myocardial performance, preserves myocardial blood flow in the ischemic canine heart. Anesth Analg 1993; 76: 1201-12.

11. Gerhardt MA, Booth JV, Chesnut $\mathrm{LC}$, et al. Acute myocardial Badrenergic receptor dysfunction after cardiopulmonary bypass in patients with cardiac valve disease. Circulation 1998 (Suppl 19): II275-281.

12. Thandroyen FT, Muntz KH, Buja LM, Willerson JT. Alterations in Badrenergic receptors, adenylate cyclase, and cyclic AMP concentrations during acute myocardial ischemia and reperfusion. Circulation 1990; 82 (Suppl 3): II30-7.

13. Schranz D, Droege A, Broede A, et al. Uncoupling of human cardiac Badrenoreceptors during cardiopulmonary bypass with cardioplegic cardiac arrest. Circulation 1993; 87: 422-6. 
14. Kikura M, Levy JH, Michelsen LG, et al. The effect of milrinone on hemodynamics and left ventricular function after emergence from cardiopulmo -nary bypass. Anesth Analg 1997; 85: 16-22.

15. Feneck RO. Effects of variable dose milrinone in patients with low cardiac output after cardiac surgery. Am Heart J 1991; 121: 1995-9.

16. Lobato EB, Florete O Jr, Bingham HL. A single dose of milrinone facilitates separation from cardiopulmonary bypass in patients with pre-existing left ventricular dysfunction. Br J Anaesth 1998; 81: 782-4.
17. Feneck RO and The European Milrinone Multicentre Trial Group. Intravenous milrinone following cardiac surgery: I. Effects of bolus infusion followed by variable dose maintenance infusion. $J$ Cardiothorac Vasc Anesth. 1992;6:554-562.

18. Colucci WS. Observations on the intracoronary administration of milrinone and dobutamine to patients with congestive heart failure. Am J Cardiol. 1989;63:17A-22A.

19. Butterworth JF IV, Hines RL, Royster RL, James RL. A pharmacokinetic and pharmacodynamic evaluation of milrinone in adults undergoing cardiac surgery. Anesth Analg 1995; 81:783-92. 


\section{تأثيرات الجرعات المختلفة من عقار ميلرينون علي ديناميكية الام و وظيفة

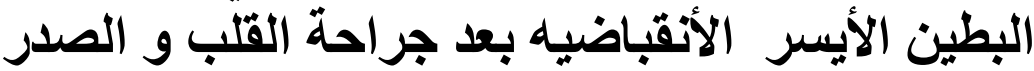

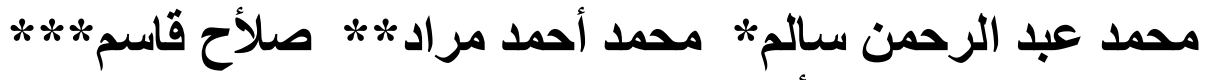

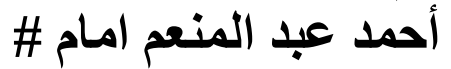

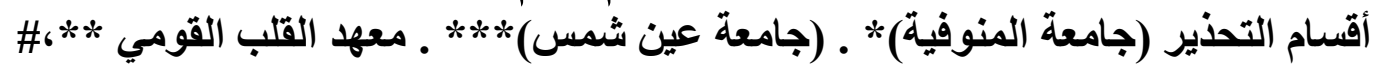

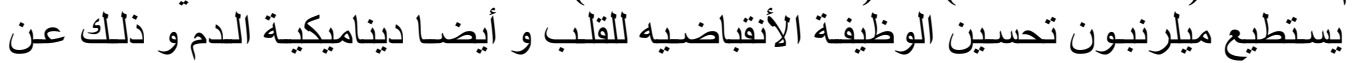

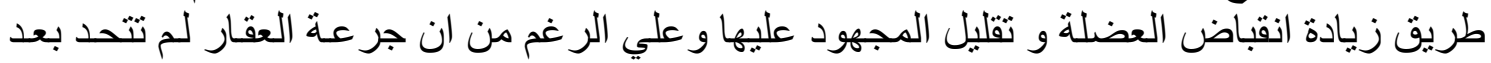

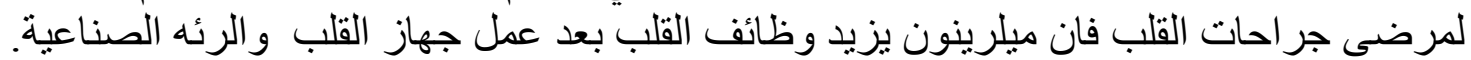

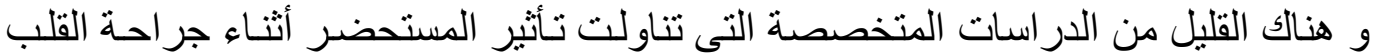

وقد تناول البحث در اسة تأثير ات الميلرنيون علي وظائف البطين الأيسر الانقباضية ودنية ودنياميكية الدام

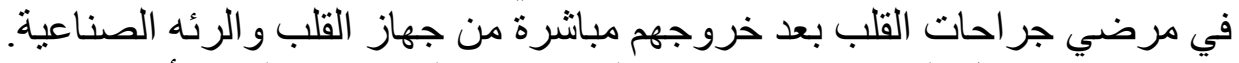

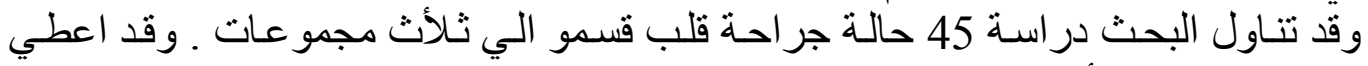

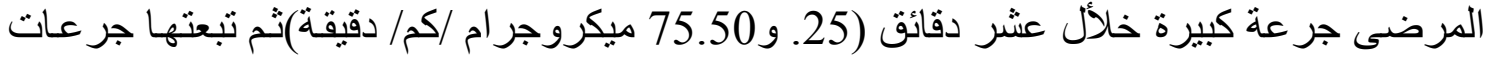

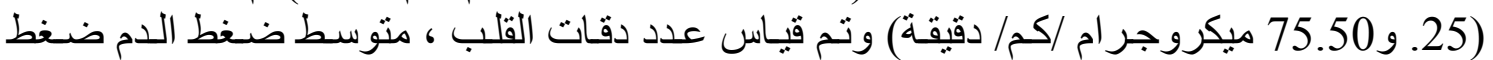

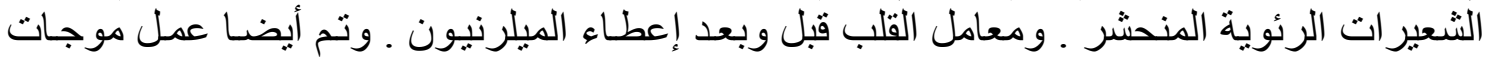

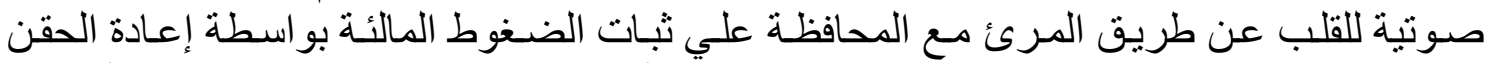

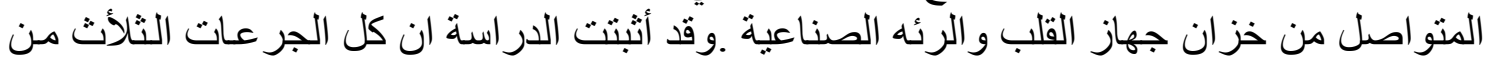

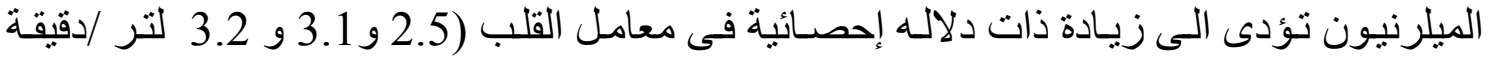

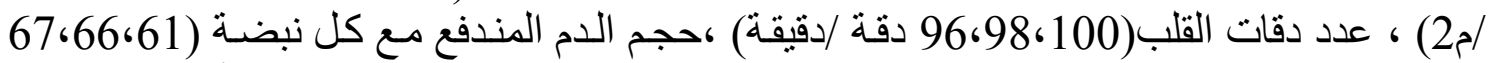

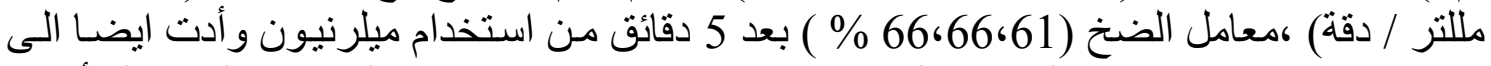

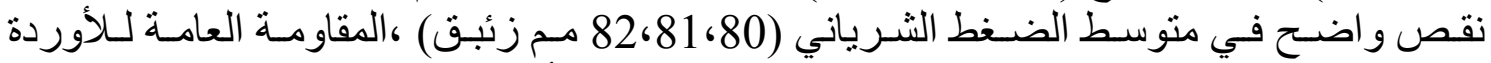

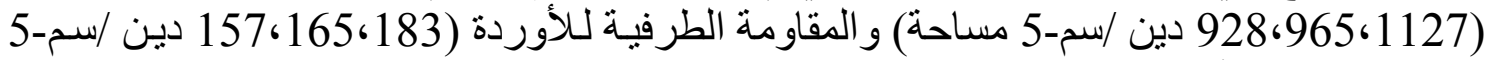

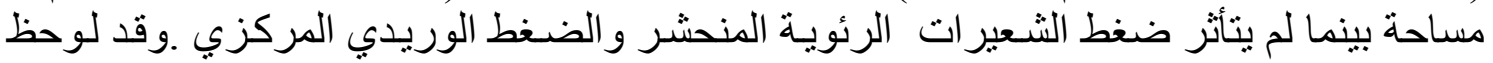

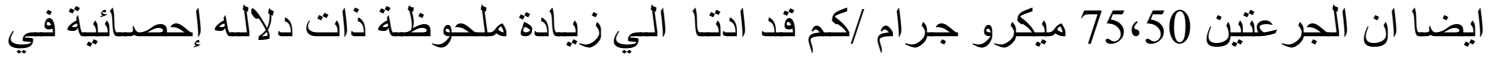

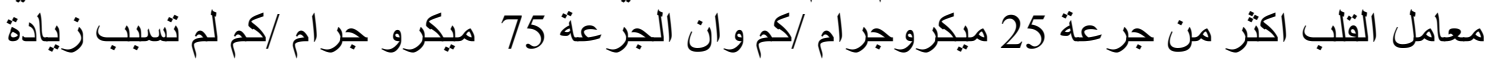

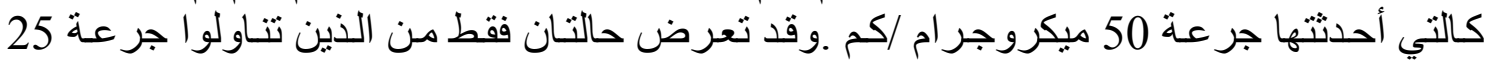

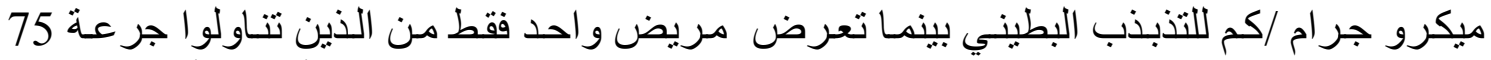

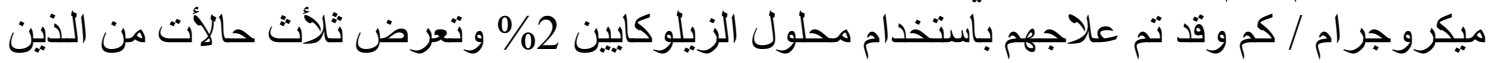

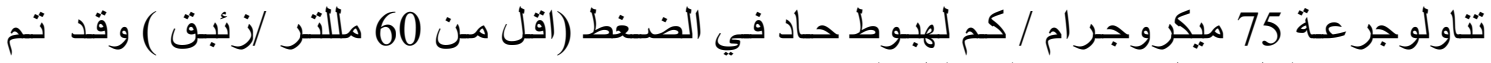
علاجهم بمحلول فينيل افرين و المحاليل التعويضية.

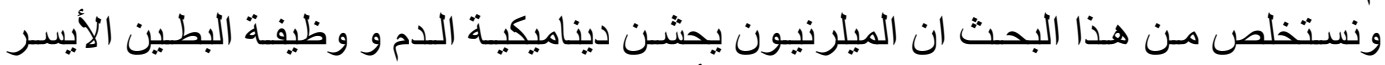

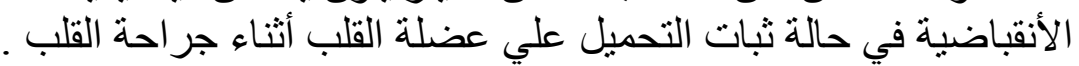

